\title{
EXPRESSION OF ER, PR AND HER2/nEU IMMUNOMARKERS IN INFILTRATING DUCT CARCINOMA BREAST IN CELL BLOCK PREPARATIONS AS COMPARED TO HISTOPATHOLOGY
}

\author{
Ginju Vijayakrishnan ${ }^{1}$, Cicy P. J², Sankar $S^{3}$
}

${ }_{1}^{1}$ Postgraduate Student, Department of Pathology, Government Medical College, Kottayam, Kerala, India.

${ }^{2}$ Associate Professor, Department of Pathology, Government Medical College, Kottayam, Kerala, India.

${ }^{3}$ Professor and HOD, Department of Pathology, Government Medical College, Kottayam, Kerala, India.

\section{ABSTRACT}

\section{BACKGROUND}

Fine-Needle Aspiration (FNA) is an easy, quick, inexpensive and reliable technique for diagnosing breast carcinomas. Assessment of Oestrogen Receptor (ER), Progesterone Receptor (PR) and Human Epidermal growth factor Receptor 2 (HER2/neu) expression in breast cancer is necessary for the selection of patients appropriate for hormonal therapy. Hormone receptor study can be done on cytological aspirates rather than on biopsies, thus avoiding a delay in starting treatment.

Aim- This study was done to compare immunostaining of these markers in cytology aspirates of infiltrating duct carcinoma breast using cell block preparations with histopathology.

\section{MATERIALS AND METHODS}

Diagnostic test evaluation was done on a study sample of 36 cases of infiltrating duct carcinoma breast received in Department of Pathology, Government Medical College, Kottayam during the study period of 12 months (October 2016 - October 2017).

\section{RESULTS}

The study population had a mean age of 56.17 years. Positivity in cell blocks and histopathology were seen in cases (\%): ER, 66.7, 69.4; PR, 52.8, 52.8 and HER2/neu, 16.7, 22.2 respectively. In the assessment of ER, PR and HER2/neu protein (3+) positivity, sensitivity, specificity, Positive Predictive Value (PPV), Negative Predictive Value (NPV) of cell blocks were as follows: ER- 96\%, 100\%, 100\% and 91.67\%; PR- 94.73\%, 94.11\%, 94.73\% and 94.11\%; HER2/neu- 75\%, 100\%, 100\% and 93.33\%. The correlation coefficient between cell block and their corresponding histopathological sections for oestrogen receptor, progesterone receptor and HER2/neu receptor immunostaining were $0.938,0.889$ and 0.837 respectively.

\section{CONCLUSION}

Positivity in cell blocks and histopathology were seen in cases (\%): ER, 66.7, 69.4; PR 52.8, 52.8; and HER2/neu, 16.7, 22.2 respectively. There is definite correlation between ER, PR and HER2/neu staining in cell blocks compared to histopathology with a correlation coefficient of $0.938,0.889$ and 0.837 respectively. So, cell blocks can be used for immunostaining, which avoids need for biopsy and delay in starting therapy.

\section{KEY WORDS}

Oestrogen Receptor (ER); Cell Block; Progesterone Receptor (PR); Human Epidermal Growth Factor Receptor 2 (HER2/neu); Histopathology; Breast Carcinoma.

HOW TO CITE THIS ARTICLE: Vijayakrishnan G, Cicy PJ, Sankar S. Expression of ER, PR and HER2/neu immunomarkers in infiltrating duct carcinoma breast in cell block preparations as compared to histopathology. J. Evolution Med. Dent. Sci. 2018;7(31): 3536-3540, DOI: $10.14260 /$ jemds/2018/794

\section{BACKGROUND}

Carcinoma breast is the most common malignancy in women and the second most common malignancy in the world. It ranks as the fifth cause of death from cancer overall and is the most frequent cause of mortality in women in less developed regions.

The therapeutic and prognostic relevance of Oestrogen Receptor (ER) and Progesterone Receptor (PR) in carcinoma breast have been studied extensively. ER is expressed by $75 \%$ of primary breast carcinomas, nearly $50 \%$ co-express PR and about $20 \%$ are ER and PR negative. Hormone receptor

'Financial or Other Competing Interest': None.

Submission 01-06-2018, Peer Review 15-07-2018,

Acceptance 21-07-2018, Published 30-07-2018.

Corresponding Author:

Dr. Cicy P. J,

Associate Professor, Department of Pathology,

Government Medical College,

Gandhinagar P. O. Kottayam-686008, Kerala, India

E-mail: selavumkal@gmail.com

DOI: $10.14260 /$ jemds $/ 2018 / 794$ determination acts primarily as a predictive factor for response towards hormonal therapy. The presence of ER is related to a favourable response to tamoxifen therapy and improved overall survival.

In numerous clinical trials, targeted therapy towards Human Epidermal growth factor Receptor 2 (HER-2)- using trastuzumab has been found to be remarkably effective against HER-2-positive carcinoma breast. This efficacy of HER-2 targeted therapy in selected patients with HER-2positive breast carcinoma provides the rationale for testing all newly diagnosed breast cancer patients for the HER-2 over-expression/ genomic alteration of the receptor protein.

The patients of breast cancer are subjected to FNA as a part of the triple assessment before proceeding on with any form of treatment. In the developing countries, FNA is in fact the most common preliminary procedure in cases of palpable breast lumps. To decide on the best possible neo-adjuvant chemotherapy or hormonal therapy, information about hormone receptor status is a must. Therefore, most of these cases undergo a second biopsy for the sole purpose of IHC. This practice in itself has many disadvantages, in that it 
exposes the patient to a second invasive procedure with an extra cost involved in the proceedings, theoretical risk of micro-metastasis and moreover there is a delay in the management. The hormone receptor status can be studied on cytology and the patients can be treated with hormonal therapy on the basis of FNAC, and thus a surgical procedure can be avoided in a good number of cases.

The aim of this study is to determine the Oestrogen Receptor (ER), Progesterone Receptor (PR), Human Epidermal growth factor Receptor 2 (HER2/neu) expression in cytology aspirates using cell block preparations and compare the results with Immunohistochemistry (IHC) on surgical material in order to get cytological and histological comparison.

\section{Objective}

To study the expression of ER, PR and HER2/neu in cytology of infiltrating duct carcinoma breast using cell block preparations and to compare immunostaining in cytological aspirates with corresponding histological sections.

\section{MATERIALS AND METHODS}

Type of Study- Diagnostic Test Evaluation.

Period of Study- 1 year (October 2016 - October 2017).

Study Setting- Department of Pathology, Government Medical College, Kottayam.

\section{Study Population}

Cell blocks are taken from all highly suspicious cases of carcinoma breast presenting to Department of Pathology, Government Medical College, Kottayam. They are followed up and cell blocks of only those patients diagnosed histologically as infiltrating duct carcinoma breast post-surgery are taken for the IHC study.

\section{Sample Size}

Sample size, N= Specificity (1-Specificity)

$$
\mathrm{d} 2 \times \mathrm{p}
$$

In a study conducted by Bueno Angelo et al, specificity of cell block in the investigation of PR was $94.7 \% .^{1}$

Specificity $=94.7 \%, d=$ absolute precision $=8 \%$, $\mathrm{p}=$ prevalence of invasive Ca breast $=23 \%{ }^{2}$

\section{Sample size, $N=\underline{0.947(1-0.947)}=\underline{0.947 \times 0.053}=34$ $0.0064 \times 0.23 \quad 0.001472$}

Sampling Method- Study sample included 36 cases of infiltrating duct carcinoma breast who presented in Department of Pathology, Government Medical College, Kottayam during the study period.

Inclusion Criteria- Highly suspicious cases included those cases suspected clinically and radiologically (With high score in BIRADS-IVc or V) to have carcinoma breast. From them only those cases reported as infiltrating duct carcinoma breast histologically were taken for immunomarker studies.

Exclusion Criteria- Patients with non-invasive carcinoma breast and pregnant patients.

\section{Study Procedure}

Cases highly suspected clinically and radiologically to have carcinoma breast were selected and their cell blocks were taken along with smears. Then they were followed up and only those cases reported as infiltrating duct carcinoma postsurgery were taken up for IHC study. Hormone receptor study was done in their tissue sections and comparison was made with immunostaining done in their corresponding cell blocks. 36 such cases were studied.

Fine-needle aspiration was performed by using a 22 - 23G needle attached to a $10 \mathrm{~mL}$ syringe. One or two passes were taken to obtain adequate material. Wet and air-dried smears were made and stained with Giemsa and Papanicolaou stains. Rest of the aspirate was fixed in AAF fixative (for 24 hours) centrifuged and from the cell button obtained cell block was prepared.

Corresponding mastectomy (24 in no.), core biopsy (7 in no.), lumpectomy (5 in no.) specimens were taken. The formalin-fixed and paraffin-embedded sections were then stained by routine $\mathrm{H}$ and $\mathrm{E}$ stain.

ER, PR and HER2/neu IHC was performed on 3-micron thick sections. Immunostaining was done on cell blocks and tissue sections and were evaluated separately. For ER and PR scoring (nuclear staining) in cell block and histopathology sections, Allred scoring system was used. The Allred score takes into consideration the percentage of positive cells and the intensity of the reaction product. A scoring system (Refer Table 1) is given for each and they are added together for a final score with 8 possible values. Scores of 0 to 2 are taken as negative. Scores of 3 to 8 are taken as positive.

\begin{tabular}{|c|c|c|c|}
\hline $\begin{array}{l}\text { Positive Cells } \\
(\%)\end{array}$ & $\begin{array}{l}\text { Proportion } \\
\text { Score }\end{array}$ & Intensity & $\begin{array}{l}\text { Intensity } \\
\text { Score }\end{array}$ \\
\hline 0 & 0 & None & 0 \\
\hline$<1$ & 1 & Weak & 1 \\
\hline $1-10$ & 2 & Intermediate & 2 \\
\hline $11-33$ & 3 & Strong & 3 \\
\hline $34-66$ & 4 & & \\
\hline$>67$ & 5 & & \\
\hline \multicolumn{4}{|c|}{$\begin{array}{c}\text { Table 1. Oestrogen and Progesterone Receptor Evaluation } \\
\text { Allred Scoring }\end{array}$} \\
\hline
\end{tabular}

HER-2 scoring in cell blocks and histopathology was done according to the Modified 2013 ASCO/CAP guidelines. Cases with 0 and $1+$ scores were considered negative, cases scored as $2+$ were taken as equivocal and cases with $3+$ score were considered as positive in the guidelines.

\begin{tabular}{|c|c|}
\hline $\begin{array}{l}\text { Results } \\
\text { (Score) }\end{array}$ & Criteria \\
\hline $\begin{array}{l}\text { Negative } \\
\quad(0)\end{array}$ & $\begin{array}{l}\text { No staining seen or }<10 \% \text { of tumour cells } \\
\text { showing incomplete, barely } \\
\text { perceptible membrane staining }\end{array}$ \\
\hline $\begin{array}{c}\text { Negative } \\
(1+)\end{array}$ & $\begin{array}{l}>10 \% \text { of tumour cells showing incomplete, } \\
\text { barely perceptible membrane staining }\end{array}$ \\
\hline $\begin{array}{l}\text { Equivocal } \\
\qquad(2+)\end{array}$ & $\begin{array}{c}>10 \% \text { of tumour cells showing incomplete and } \\
\text { weak-to-moderate circumferential } \\
\text { membrane staining or }</=10 \% \text { of invasive } \\
\text { tumour cells showing intense, circumferential, } \\
\text { complete membrane staining }\end{array}$ \\
\hline $\begin{array}{c}\text { Positive } \\
(3+)\end{array}$ & $\begin{array}{l}>10 \% \text { of invasive tumour cells showing intense, } \\
\text { circumferential, complete membrane staining }\end{array}$ \\
\hline
\end{tabular}


Only HER2/neu strong positive (score $3+$ ) cases are considered positive in our study. Score $0,1+$ and $2+$ are considered negative.

\section{Data Management and Analysis}

The data was entered in Microsoft Excel and further statistical analysis was done using SPSS software (version 20). The statistical methods used were mean, frequency, proportion, sensitivity, specificity, positive predictive value and negative predictive value. Non-parametric test (Kendall tau-b) was used for assessing correlation. The level of significance was indicated by correlation coefficient (between 0 and 1).

\section{RESULTS}

Diagnostic test evaluation was done on 36 cases of infiltrating duct carcinoma breast who presented to Department of Pathology, Government Medical College, Kottayam during the study period of 12 months.

- $\quad$ The present study population had a mean age of 56.17 years (Standard deviation- 11.338). Minimum age was 40 years and maximum was 86 years. Majority belonged to age of 50 - 60 years (41.7\%).

- $\quad$ Left breast was more involved (53\%) than right.

- $72.2 \%$ of patients had symptoms lasting for 1 week - 6 months.

- In the present study, $69.4 \%$ had a lesion graded BIRADSV in Radiology, while $30.6 \%$ had BIRADS-IV.

- Upper outer quadrant was involved by the malignancy in majority (50\%) of the study population.

- $\quad$ Skin involvement was found in $83.3 \%$.

- $\quad 52.8 \%$ had lymph node involvement.

- Majority (72.2\%) had Grade II malignancy.

- 24 cases were ER positive (66.7\%) and 12 cases were ER negative (33.3\%) in cell block. 25 cases were ER positive (69.4\%) and 11 cases were ER negative (30.6\%) in histopathology. $25 \%$ had strong ER positivity (score 8 ) in cell block, while $36.1 \%$ had strong ER positivity (score 8) in histopathology.

- 19 cases were PR positive (52.8\%), while 17 cases were PR negative $(47.2 \%)$ in cell block. Similarly, 19 cases were PR positive (52.8\%) and 17 cases were PR negative (47.2\%) in histopathology. $11.1 \%$ cases had strong PR positivity (score 8 ) in cell block, while $16.7 \%$ had strong PR positivity (score 8) in histopathology.

- 6 cases were strong HER2/neu positive- $3+(16.7 \%), 1$ case $(2.8 \%)$ was equivocal and 29 cases $(80.6 \%)$ were HER2/neu negative in cell block. 8 cases showed strong HER2/neu positivity- $3+(22.2 \%), 3$ cases $(8.3 \%)$ were equivocal, while 25 cases $(69.5 \%)$ were HER2/neu negative on histopathology.

- In determining ER cell blocks had a sensitivity of $96 \%$, specificity of $100 \%$, positive predictive value of $100 \%$, Negative Predictive Value (NPV) of $91.67 \%$.

- In determining PR, cell blocks had a sensitivity of $94.73 \%$, specificity of $94.11 \%$, positive predictive value of $94.73 \%$, Negative Predictive Value (NPV) of $94.11 \%$.

- In determining HER2/neu (3+) cell blocks had a sensitivity of $75 \%$, specificity of $100 \%$, positive predictive value of $100 \%$, negative predictive value (NPV) of $93.33 \%$.
- The correlation coefficient between cell block and corresponding histopathological sections for ER, PR and HER2/neu were $0.938,0.889$ and 0.837 .

\begin{tabular}{|c|c|c|c|}
\hline \multirow{2}{*}{ ER CB } & \multicolumn{2}{|c|}{ ER HP } & \multirow{2}{*}{ Total } \\
\cline { 2 - 3 } & Positive & Negative & \\
\hline Positive & 24 & 0 & 24 \\
\hline Negative & 1 & 11 & 12 \\
\hline Total & $\mathbf{2 5}$ & $\mathbf{1 1}$ & $\mathbf{3 6}$ \\
\hline
\end{tabular}

Table 3. ER in Cell Block vs ER in histopathology cross table to assess Sensitivity, Specificity, PPV, NPV of cell blocks in assessing ER

\begin{tabular}{|c|c|c|c|}
\hline \multirow{2}{*}{ PR CB } & \multicolumn{2}{|c|}{ PR HP } & \multirow{2}{*}{ Total } \\
\hline & Positive & Negative & \\
\hline Positive & 18 & 1 & 19 \\
\hline Negative & 1 & 16 & 17 \\
\hline Total & 19 & 17 & 36 \\
\hline \multicolumn{4}{|c|}{$\begin{array}{c}\text { Table 4. PR in Cell Block vs PR in histopathology cross } \\
\text { table to assess Sensitivity, Specificity, PPV, } \\
\text { NPV of cell blocks in assessing PR }\end{array}$} \\
\hline
\end{tabular}

\begin{tabular}{|c|c|c|c|}
\hline \multirow{2}{*}{ HER-2 CB } & \multicolumn{2}{|c|}{ HER-2 HP } & \multirow{2}{*}{ Total } \\
\cline { 2 - 3 } & Positive & Negative & \\
\hline Positive & 6 & 0 & 6 \\
\hline Negative & 2 & 28 & 30 \\
\hline Total & 8 & 28 & 36 \\
\hline Table 5. HER2/neu in cell block vs HER2/neu in \\
histopathology cross table- to assess Sensitivity, \\
Specificity, PPV, NPV of cell blocks in assessing HER2/neu \\
\hline
\end{tabular}

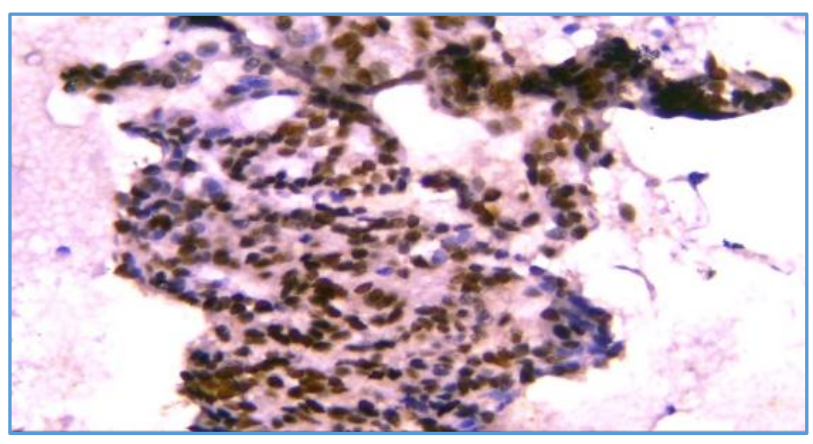

Figure 1. Photomicrograph-Cell Block with strong ER Positivity (Score 8)- $40 \mathrm{X}$

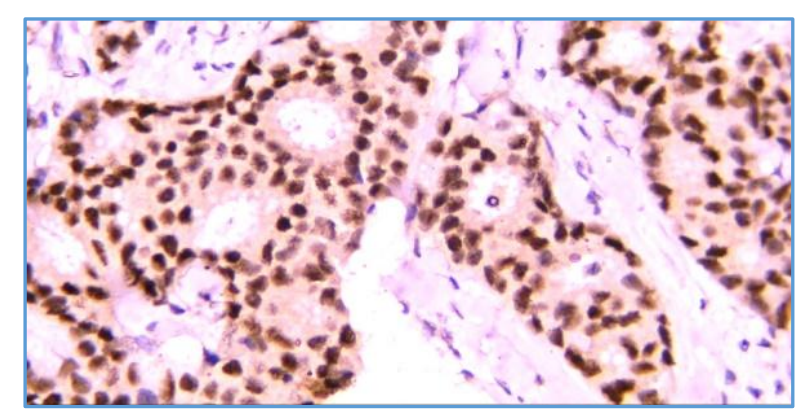

Figure 2. Photomicrograph-MRM with strong ER Positivity (Score 8)- $40 \mathrm{X}$ 


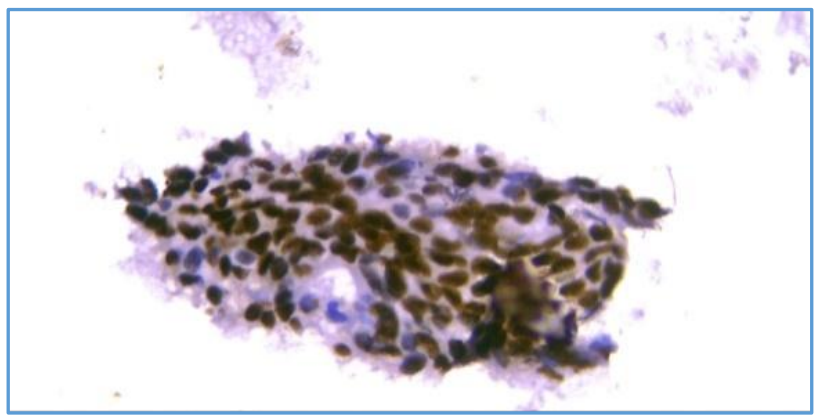

Figure 3. Photomicrograph-Cell Block with strong PR Positivity (Score 8)- $40 \mathrm{X}$

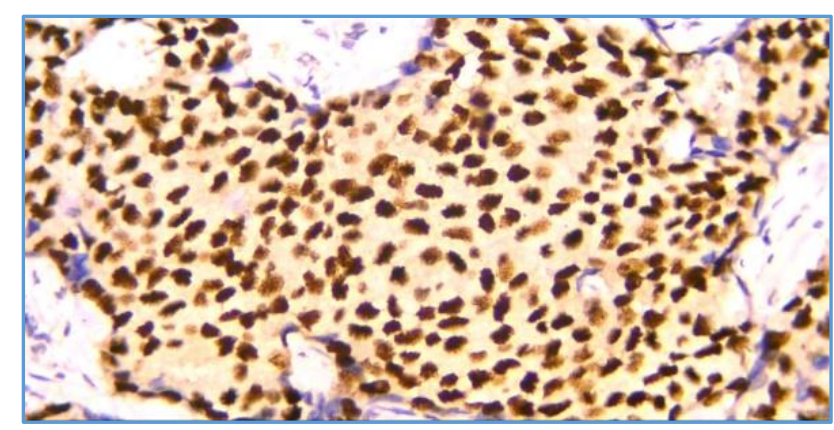

Figure 4. Photomicrograph-MRM with strong PR Positivity (Score 8)- $40 X$

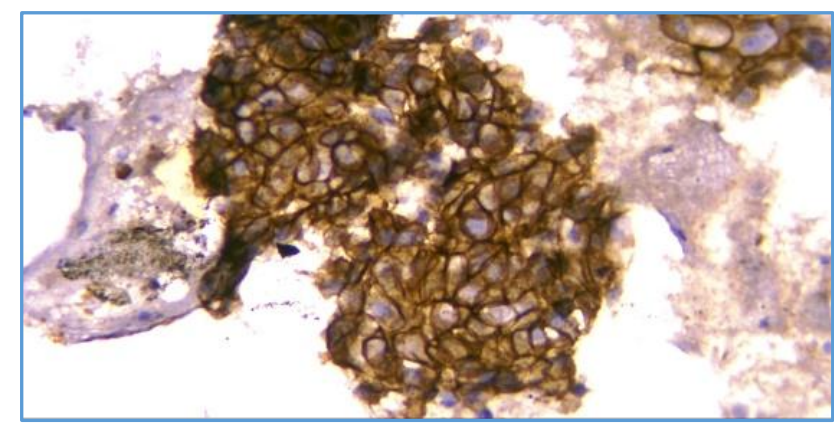

Figure 5. Photomicrograph-Cell Block with strong HER2/neu Positivity (Score 3+)- $40 \mathrm{X}$

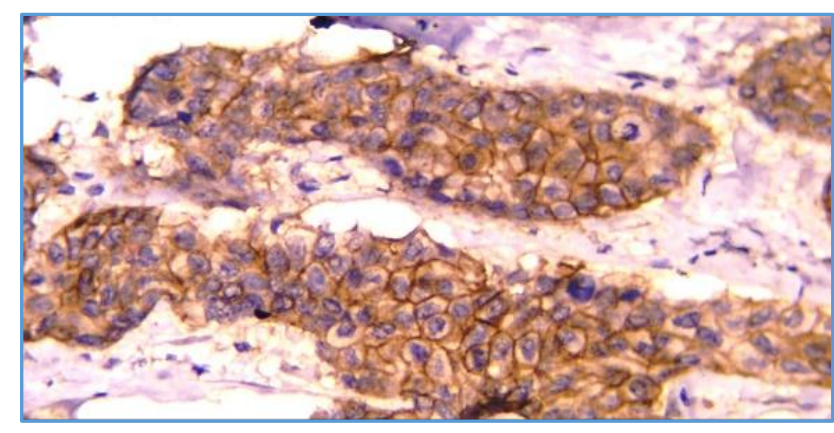

Figure 6. Photomicrograph-MRM with strong HER2/Neu Positivity (Score 3+)- $40 \mathrm{X}$

\section{DISCUSSION}

Fine needle aspiration is an inexpensive and accurate technique for the detection of breast carcinomas. Immunohistochemistry for hormonal assessment in breast cancers is routinely performed and is valuable for detecting cases amenable for hormonal therapy. Several studies have pointed out that hormone receptor status in cytological specimens correlates well with the corresponding histological specimens and can be used instead of them for early initiation of treatment.

\begin{tabular}{|c|c|c|c|}
\hline & $\begin{array}{c}\text { Present } \\
\text { Study }\end{array}$ & $\begin{array}{c}\text { Wu H et } \\
\mathbf{a l}^{\mathbf{4}}\end{array}$ & $\begin{array}{c}\text { Marianne } \\
\text { Briffod et al5 }\end{array}$ \\
\hline ER Positivity & $66.7 \%$ & $62 \%$ & $69 \%$ \\
\hline PR Positivity & $52.8 \%$ & $37 \%$ & $31 \%$ \\
\hline $\begin{array}{c}\text { HER2/neu } \\
\text { Positivity }\end{array}$ & $16.7 \%$ & $18 \%$ & $49 \%$ \\
\hline
\end{tabular}

Table 6. Comparison of Expression of ER, PR and HER2/neu positivity in cell blocks with Other Studies

The ER positivity obtained in cell blocks in the present study is comparable with other similar studies done on cell blocks. Differences in PR and HER2/neu may be due to present study being done in a small number of cases. Values close to cut-off time and duration of fixation also influences the result.

The results of the current study also demonstrate good correlation of ER, PR and HER2/neu IHC performed on tissue block and cell block material.

Sensitivity, specificity, Positive Predictive Value (PPV) and Negative Predictive Value (NPV) of cell block in determining hormone receptors and HER2/neu status as compared to other studies are given below:

\begin{tabular}{|c|c|c|c|}
\hline ER & $\begin{array}{c}\text { Present } \\
\text { Study }\end{array}$ & $\begin{array}{c}\text { SP Bueno } \\
\text { Angela et al }\end{array}$ & $\begin{array}{c}\text { Shabaik } \\
\text { et al6 }\end{array}$ \\
\hline Sensitivity & $96 \%$ & $92.7 \%$ & $85.7 \%$ \\
\hline Specificity & $100 \%$ & $85.7 \%$ & $100 \%$ \\
\hline PPV & $100 \%$ & $92.7 \%$ & $100 \%$ \\
\hline NPV & $91.67 \%$ & $85.7 \%$ & $85.7 \%$ \\
\hline \multicolumn{4}{|c|}{ Table 7. Cell Blocks in ER Assessment- Comparison with } \\
Other Studies \\
\hline
\end{tabular}

In our study sensitivity, specificity, positive predictive value and negative predictive value was found to be high for cell blocks in determining ER status.

\begin{tabular}{|c|c|c|c|}
\hline PR & $\begin{array}{c}\text { Present } \\
\text { Study }\end{array}$ & $\begin{array}{c}\text { SP Bueno } \\
\text { Angela et al }\end{array}$ & Shabaik et al6 $^{6}$ \\
\hline Sensitivity & $94.73 \%$ & $92.7 \%$ & $80 \%$ \\
\hline Specificity & $94.11 \%$ & $94.7 \%$ & $100 \%$ \\
\hline PPV & $94.73 \%$ & $97.4 \%$ & $100 \%$ \\
\hline NPV & $94.11 \%$ & $87 \%$ & $88.8 \%$ \\
\hline \multicolumn{4}{|c|}{ Table 8. Cell Blocks in PR Assessment- Comparison with } \\
Other Studies \\
\hline
\end{tabular}

In our study sensitivity, specificity, positive predictive value and negative predictive value was found to be high for cell blocks in determining PR status.

\begin{tabular}{|c|c|c|}
\hline HER2/neu & Present Study & SP Bueno Angela et al \\
\hline Sensitivity & $75 \%$ & $70 \%$ \\
\hline Specificity & $100 \%$ & $100 \%$ \\
\hline PPV & $100 \%$ & $100 \%$ \\
\hline NPV & $93.33 \%$ & $94.5 \%$ \\
\hline
\end{tabular}

Table 9. Cell Blocks in HER2/neu Assessment-Comparison with Other Studies

In our study sensitivity, specificity, positive predictive value and negative predictive value was found to be high for cell blocks in determining HER2/neu status.

Even though our study showed excellent concordance between cell blocks and corresponding surgical specimens, few discordant results were also seen, probably due to fixation causing change in antigenicity. Cytoplasmic as well as 
background staining in cell block immunostaining is another factor causing minor errors in interpretation.

\begin{tabular}{|c|c|c|c|}
\hline Correlation Coefficient & ER & PR & HER2/neu \\
\hline Present study & 0.938 & 0.889 & 0.837 \\
\hline Kumar SK et al ${ }^{7}$ & 0.79 & 0.86 & 0.76 \\
\hline Williams SL et al & 0.76 & 0.79 & 0.56 \\
\hline $\begin{array}{c}\text { Table 10. Comparison of correlation (between } \\
\text { immunostaining in cell blocks and histopathology) with } \\
\text { Other Studies }\end{array}$ \\
\hline
\end{tabular}

The current study was undertaken in 36 cases of invasive carcinoma breast for immunostaining in cell blocks and to compare it with corresponding histopathology specimens. They demonstrate good concordance for ER, PR and HER2/neu and hence immunostaining in cell blocks for ER, PR and HER2/neu may be recommended.

\section{Limitations of the Study}

Sample size is small. Equivocal cases of HER2/neu is not correlated with FISH in the study.

\section{CONCLUSION}

1. Expression of positivity is: ER- $66.7 \%$, PR- $52.8 \%$, HER2/neu- $16.7 \%$ (in cell block preparations of infiltrating duct carcinoma breast).

2. Correlation of expression in cell block preparations as compared to histopathology are (correlation coefficient)ER- 0.938, PR- 0.889, HER2/neu- 0.837.

Since the expression is reasonably good in cell blocks and correlation is good with histopathology, performing immunohistochemical procedures for these markers in cell blocks in infiltrating duct carcinoma breast may be recommended.

\section{REFERENCES}

[1] Angela BSP, Viero RM, Soares CT. Fine needle aspirate cell blocks are reliable for detection of hormone receptors and HER-2 by immunohistochemistry in breast carcinoma. Cytopathology 2013;24(1):26-32.
[2] Colditz G, Chia KS. Invasive breast carcinoma: introduction and general features. In: Lakhani SR, Ellis IO, eds. WHO classification of tumors of the breast. Lyon: IARC Press 2012: p. 14-23.

[3] Fitzgibbons PL, Dillon DA, Alsabeh R, et al. Template for reporting results of biomarker testing of specimens from patients with carcinoma of the breast. Archives of Pathology \& Laboratory Medicine 2014;138(5):595-601.

[4] Wu HH, Alderman M. Hormone receptor assessment of metastatic breast carcinoma by fine needle aspiration utilizing cell blocks and cell transfer techniques: an immunocytochemical review of 163 consecutive cases. Cytology \& Tissue Biology 2016;3(1):1-4.

[5] Briffod $M$, Hacène $K$, Doussal VL. Immunohistochemistry on cell blocks from fine-needle cytopunctures of primary breast carcinomas and lymph node metastases. Modern Pathology 2000;13(8):841-50.

[6] Shabaik A, Lin G, Peterson M, et al. Reliability of HER2/neu, estrogen receptor and progesterone receptor testing by immunohistochemistry on cell block of FNA and serous effusions from patients with primary and metastatic breast carcinoma. Diagn Cytopathol 2011;39(5):328-32.

[7] Kumar SK, Gupta N, Rajwanshi A, et al. Immunochemistry for oestrogen receptor, progesterone receptor and HER-2 on cell blocks in primary breast carcinoma. Cytopathology 2012;23(3):181-6.

[8] Williams SL, Birdsong GG, Cohen C, et al. Immunohistochemical detection of estrogen and progesterone receptor and HER-2 expression in breast carcinomas: comparison of cell block and tissue block preparations. Int J Clin Exp Pathol 2009;2(5):476-80. 